\title{
SCIENTIFIC REP

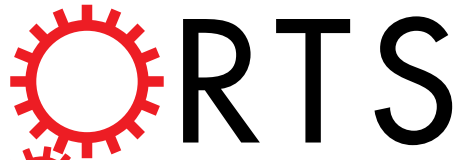 \\ OPEN Erratum: A mineralogical study in contrasts: highly mineralized whale rostrum and human enamel
}

\section{Zhen Li, Maisoon Al-Jawad, Samera Siddiqui \& Jill D. Pasteris}

Scientific Reports 5:16511; doi: 10.1038/srep16511; published online 10 November 2015; updated 08 January 2018

The original version of this Article contained a typographical error in the spelling of the author Maisoon Al-Jawad, which was incorrectly given as Maisoon AI-Jawad. This has now been corrected in the PDF and HTML versions of the Article.

(c) (i) This work is licensed under a Creative Commons Attribution 4.0 International License. The images or other third party material in this article are included in the article's Creative Commons license, unless indicated otherwise in the credit line; if the material is not included under the Creative Commons license, users will need to obtain permission from the license holder to reproduce the material. To view a copy of this license, visit http://creativecommons.org/licenses/by/4.0/

(C) The Author(s) 2018 